\title{
Is soluble ST2 a new marker in heart failure?
}

\author{
Dildar Konukoglu \\ Department of Medical Biochemistry, Istanbul University, Cerrahpasa Faculty of Medicine, Istanbul, Turkey
}

\begin{abstract}
Objectives: The clinical diagnosis of heart failure (HF) is based on a history and a physical examination. Circulating molecules, such as troponin, B-type natriuretic peptide, and N-terminal pro-B-type natriuretic peptide are useful in the management of HF. Recently, it has been reported that a new biomarker, suppression of tumorigenicity (ST2), was associated with the prognosis of HF. ST2 is a cytokine and has 2 isoforms, a soluble (sST2) and a transmembrane receptor (ST2 ligand, or ST2L). The effects of ST2 are related to it binding to interleukin 33, which is a proinflammatory cytokine. SST2 acts as a decoy receptor in these interactions. SST2 plays a role not only in the pathogenesis of HF, but also in the pathogenesis of atherosclerosis. Additionally, an increased blood concentration of sST2 has been reported in several diseases. The most commonly used method is enzyme-linked immunoassay. However, there have been some methodological problems in the analysis of SST2. The aim of this review was to explore the biology and analytical considerations of ST2 and its clinical importance in HF.
\end{abstract}

Keywords: Cardiac marker, heart failure, inflammation, interleukin 33, soluble ST2

$\mathrm{H}^{\mathrm{e}}$ eart failure (HF) is a chronic, progressive, complex cardiovascular disorder and is a major general health problem. HF results from structural or functional impairment of ventricular filling or ejection of blood. HF, whether due to systolic or diastolic dysfunction, is characterized by ventricular remodeling and variable degrees of myocardial fibrosis in response to cardiac injury or stress. The prevalence of HF has been increasing significantly with the aging population; it is now more than 23 million worldwide, and it remains a leading cause of mortality. To reduce the mortality and morbidity rates, the accurate identification of disease severity is very important in the management of HF [1, 2].

There is no single diagnostic test for HF. A clinical diagnosis of $\mathrm{HF}$ is based on a careful history and a physical examination. Some circulating molecules associated with inflammation, oxidative stress, vascular dysfunction, and myocardial and matrix remodeling have been identified and developed for $\mathrm{HF}$ management. Among these molecules, troponin, B-type natriuretic peptide (BNP) and N-terminal pro-B-type natriuretic peptide
(NT-proBNP) are already acknowledged in HF guidelines [3, 4]. According to the 2017 Report of the American College of Cardiology/American Heart Association, measurement of BNP or NTproBNP is useful in establishing the prognosis or disease severity in chronic HF and is useful in determining the prognosis in acutely decompensated HF. In addition, it was suggested in this guideline that during a HF hospitalization, a predischarge natriuretic peptide level can be useful in establishing a post discharge prognosis. Like natriuretic peptides, the cardiac troponin level may be elevated in the setting of chronic or acute decompensated $\mathrm{HF}$, indicating myocyte injury or necrosis [5].

An elevated plasma level of natriuretic peptide biomarkers is associated with a wide variety of cardiac (HF, acute coronary syndromes, heart muscle disease, valvular heart disease, cardiac surgery, etc.) and noncardiac (obesity, advancing age, anemia, renal failure, critical illness, etc.) causes [6, 7]. Troponins are also similarly increased in acute coronary syndromes and acute decompensated HF [8]. Therefore, the prognostic utility of natriuretic peptides and troponins is limited and their roles in guid- 


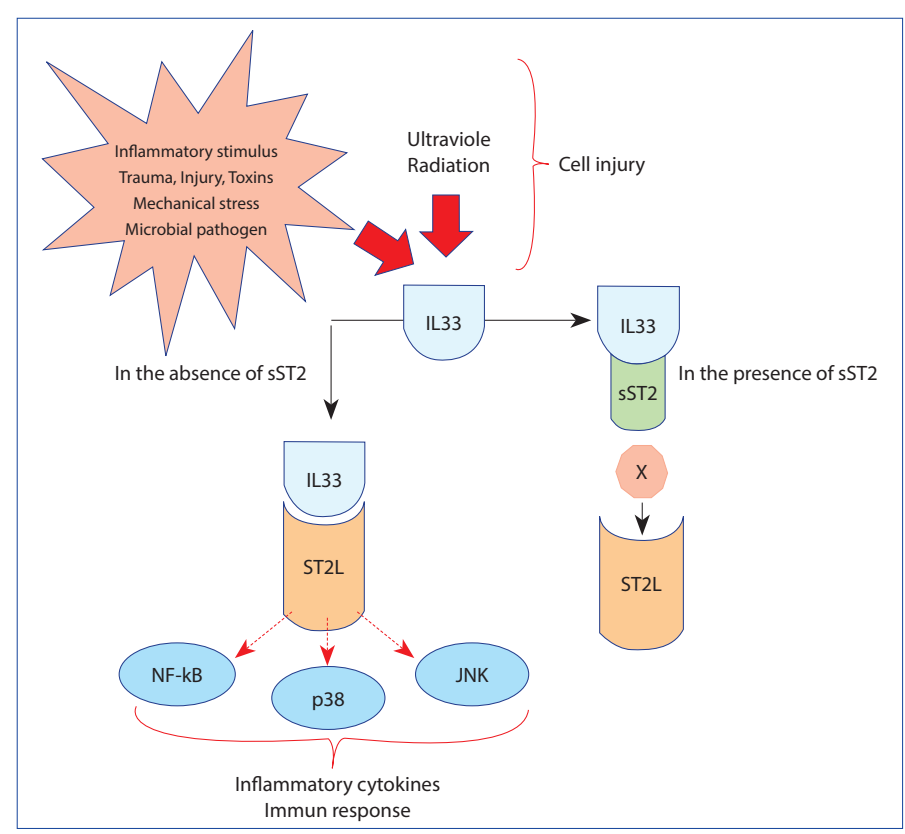

Figure 1. The interaction of interleukin 33 (IL-33) and the transmembrane receptor ST2 ligand (ST2L) activates mitogenactivated protein kinases and several biochemical pathways. The binding of soluble ST2 (sST2) to IL-33 results in the inhibition of the interaction between IL-33 and ST2L; SST2 acts as a decoy receptor in these interactions. An increased concentration of SST2 in the circulation attenuates the systemic biological effects of IL-33 on inflammatory processes.

JNK: C-Jun N-terminal kinase; NF-kB: Nuclear factor-kappa B.

ing treatment have not yet been clearly established. Thus, new molecular biomarker strategies to manage such patients are needed. Recently a new biomarker has become commercially available: suppression of tumorigenicity (ST2) $[9,10]$.

\section{Biology of ST2}

ST2 is a member of the Toll-like/interleukin (IL)-1 receptor superfamily. Due to its cell-signaling capacities, IL-1 plays a central role in the regulation of immune and inflammatory responses and is linked to the processes of infection and inflammation. The ST2 gene is located on human chromosome 2q12. Through alternative splicing, there are 2 isoforms of ST2: a soluble or serum circulating receptor ST2 (sST2) and a transmembrane receptor ST2 ligand (ST2L). ST2L contains an extracellular domain of linked immunoglobulin-like motifs, a transmembrane segment, and an intracellular cytoplasmic domain, whereas sST2 lacks the transmembrane and cytoplasmic domains. The extracellular immunoglobulin domain of ST2 has high homology to the same region of the IL-1 receptor. Although it is known that ST2L is constitutively expressed primarily in hematopoietic cells, the source(s) of circulating SST2 remains unknown. The expression of SST2 is largely inducible and almost ubiquitous in living cells, such as resting fibroblasts. It has been suggested that SST2 is produced by both cardiac fibroblasts and cardiomyocytes in re- sponse to injury or stress, and by macrovascular (aortic and coronary artery) and heart microvascular endothelial cells in response to diastolic load [9-12].

Until 2005, it was thought that ST2, as an important mediator in the inflammatory process, was associated with various inflammatory or immune diseases, such as asthma, pulmonary fibrosis, rheumatoid arthritis, vascular diseases, and septic shock [13-15]. The discovery of IL-33 in 2005 offered a new approach regarding the signaling mechanisms of ST2. IL-33 is expressed by a wide variety of cell types, including fibroblasts, mast cells, dendritic cells, macrophages, osteoblasts, endothelial cells, and epithelial cells, and induces helper T cells, mast cells, eosinophils, and basophils to produce type $2 \mathrm{cy}$ tokines [16]. IL-33 acts intracellularly as a nuclear factor (independently binding to the ST2L receptor) with transcriptional regulatory properties, and extracellularly as a pro-inflammatory cytokine [17]. In vitro, IL-33 antagonizes the effects of angiotensin-II and phenylephrine-mediated activation of nuclear factor kappa beta (NF-kB) in cardiomyocytes, an effect that is antagonized by ST2. As a cytokine, IL-33 binds to a receptor complex comprised of ST2L (also known as IL1RL1) and IL-1-receptor accessory protein. The interaction of IL-33 and ST2L activates mitogen-activated protein kinases and several biochemical pathways, including the activation of the inhibitor of NF-kB kinase signaling pathways. Thus, IL-33/ $\mathrm{ST} 2 \mathrm{~L}$ signaling is involved in the immune response through the activation of T helper 2 effector cells and the release of T helper 2-related type 2 cytokines. IL-33/ST2L interactions are also related to several inflammatory diseases [18]. On the other hand, the binding of SST2 to IL-33 results in the inhibition of the interaction between IL-33 and ST2L; SST2 acts as a decoy receptor in these interactions. Thus, increased concentrations of $\mathrm{SST} 2$ in the circulation attenuate the systemic biological effects of IL-33 on T helper 2-dependent inflammatory processes [19]. Finally, ST2 systems have both inhibiting (through its interaction with sST2) and stimulatory (through its interaction with ST2L) effects on the effects of IL-33 (Figure 1).

In experimental studies, it has been shown that the expression of IL-33 and SST2 in both cardiac fibroblasts and cardiomyocytes increased in response to myocardial stress. Weingberg et al. [20] reported that ST2 was the most highly induced transcript in response to biomechanical stress, and SST2 and ST2L forms were induced in rat neonatal cardiomyocytes subjected to cyclic strain. In myocardial infarction models, myocardial expression of ST2 and serum ST2 was transiently increased in rats. It has been shown experimentally that the interaction between IL33 and ST2L reduces myocardial fibrosis, prevents cardiomyocyte hypertrophy, reduces apoptosis, and improves myocardial function [21, 22]. By blocking the $\mathrm{ST} 2 \mathrm{~L}$ receptor, the antihypertrophic and antiapoptotic effects of IL-33 were inhibited in cardiomyocytes [23]. Finally, experimental data are indicative of a cardioprotective role for IL-33 and ST2L signaling in cardiomyocytes. In other words, IL-33 shows specific, beneficial effects through the ST2L receptor. 
Table 1. Clinical conditions in which soluble ST2 level was evaluated other than heart disease or cardiovascular disease

\begin{tabular}{|c|c|c|}
\hline Disorders & Clinical conditions & References \\
\hline \multirow[t]{3}{*}{ Infections } & Sepsis & 13 \\
\hline & HIV infection & 54 \\
\hline & Mild or severe influenza & 55 \\
\hline \multirow[t]{2}{*}{ Pulmonary diseases } & Chronic obstructive pulmonary disease & 56 \\
\hline & Allergic airway diseases & 57 \\
\hline \multirow[t]{2}{*}{ Liver diseases } & Liver failure & 58 \\
\hline & Primary biliary cirrhosis & 59 \\
\hline \multirow[t]{3}{*}{ Cancer } & Gastric cancer & 60 \\
\hline & Breast cancer & 61 \\
\hline & Hepatocellular carcinoma & 62 \\
\hline \multirow[t]{2}{*}{ Endocrine disorders } & Type 2 diabetes & 63 \\
\hline & Obesity & 64 \\
\hline \multirow[t]{2}{*}{ Inflammatory diseases } & Bowel disease & 65 \\
\hline & Skin disorders, atopic dermatitis & 66 \\
\hline \multirow[t]{5}{*}{ Immune diseases } & Autoimmune diseases & 12 \\
\hline & Rheumatoid arthritis & 67 \\
\hline & Sjogren syndrome & 68 \\
\hline & Systemic lupus erythematous & 69 \\
\hline & Behcet's disease & 70 \\
\hline \multirow[t]{3}{*}{ Neurological diseases } & Alzheimer's disease-like pathology & 71 \\
\hline & Amyotrophic lateral sclerosis & 72 \\
\hline & Stroke & 73 \\
\hline \multirow[t]{2}{*}{ Renal diseases } & End-stage renal disease & 74 \\
\hline & Membranous nephropathy & 75 \\
\hline
\end{tabular}

In contrast to the cardioprotective effects of IL33/ST2L signaling, it has been reported that the addition of excessive amounts of SST2 result in blocking the beneficial effects of IL-33. In a model with acute myocardial infarction in rats, the mRNA cardiac expression levels of sST2 were rapidly upregulated during the first 4 weeks and positively correlated with the cardiac gene expression of remodeling markers, such as inflammatory and fibrosis markers [24]. In addition, it was reported in that study that no correlation was found between the IL-33 level and cardiac remodeling markers or between sST2 and apoptosis markers. Additionally, in a model of atherosclerosis, IL-33 treatment reduced atherosclerotic plaque size, macrophage, and T cell accumulation in the aortic sinus, and induced T helper 2 cytokines and oxidized-low-density lipoprotein. Furthermore, sST2 co-treatment was related to the development of larger atherosclerotic plaque and increased $\mathrm{T}$ helper 1 response [25]. These results suggest that sST2 was involved in not only the pathogenesis of HF but also the pathogenesis of atherosclerosis. The plasma/serum concentrations of sST2 increase in inflammatory conditions, rheumatoid arthritis, type 2 diabetes mellitus, sepsis, autoimmune diseases, liver failure, cancers, fibroproliferative diseases, and ulcerative colitis (Table 1). Therefore, more research is needed to clarify the roles of extracardiac $\mathrm{sSH} 2$ in pathological events [26].

\section{Assays of Soluble ST2}

There are commercially available, ready-to-use assay kits to measure human sST2 in serum/plasma. Enzyme-linked immunosorbent assays (ELISAs) are frequently used for the measurement of human SST2 in blood. Although more than 20 different ELISA kits for the measurement of human sST2 are commercially available, only 1 method has been cleared by the US Food and Drug Administration (FDA) and received the European Conformity Mark (Presage ST2 assay; Critical Diagnostics, San Diego, CA, USA). Recently, a rapid quantitative lateral flow immunoassay for the measurement of SST2 in human plasma has been developed for point-of-care testing, but it has yet to be approved by the FDA [27].

These assays have a detection limit of 0.002 to $1.3 \mathrm{ng} / \mathrm{mL}$. The measurement ranges from 1.2 to $200 \mathrm{ng} / \mathrm{mL}$. The interassay and intraassay coefficient of variation of these methods is between $6 \%$ and $10 \%$ and between $6 \%$ and $12 \%$, respectively. Regression analysis revealed that there were major differences between methods. Concentrations of sST2 obtained with these assays are not directly comparable [27-28]. Differences between assays have also resulted from different standards and/or different antibodies, as well as different reagents and buffers. For this reason, understanding the distinctions between these assays will be important in the evaluation of published articles. It is unclear if the sum of "free sST2" and 
"complexed sST2" were measured by ELISA because of the presentation of both free sST2 and complexed sST2 (sST2 bound IL-33) in blood circulation.

It has been reported that SST2 in plasma/serum was stable for 2 days at room temperature, for at least 1 week at $4^{\circ} \mathrm{C}$, and for at least 18 months at $-20^{\circ} \mathrm{C}$ and at $-80^{\circ} \mathrm{C}$. There are no significant analytical interferences reported for ST2 from bilirubin, hemoglobin, triglycerides, cholesterol, total protein, or 49 therapeutic substances [27-30].

\section{Blood Level of Soluble ST2}

The most comprehensive study about the blood concentration of healthy subjects was conducted by Dieplinger et al. [27]. They reported that age-independent reference values were 3-28 U/mL in males $(\mathrm{n}=338)$, and 2-16 U/mL in females $(n=190)$ and the overall mean for sST2 concentration was 12 $\mathrm{U} / \mathrm{mL}$ (median: $10 \mathrm{U} / \mathrm{mL}$; range: 5-34 U/mL). Another result of the study was that the difference required for 2 serial measurements of sST2 (referred to as the reference change value, RCV) for healthy individuals was $29.8 \%$ (index of individuality was calculated at $2.77 ; \mathrm{p}<0.05$ ) and the mean non-fasting sST2 concentration was higher than the fasting concentration (about 5\%). Then the assay's manufacturer amended the analyte concentration definition to be in units of $\mathrm{ng} / \mathrm{mL}$ rather than $\mathrm{U} / \mathrm{mL}$. Wu et al. [31] tested the analytical, intraindividual, and interindividual variation for sST2 and found that the RCV and the index of individuality was 30\% and 0.25 , respectively, and the 95th percentile limit for the Presage assay was $52.1 \mathrm{ng} / \mathrm{mL}$ for men and $33.6 \mathrm{ng} / \mathrm{mL}$ for women. The notable points of the studies on biological variability are that the effects of confounding variables such as age, sex, renal function, and body mass index (BMI) are not included.

In a study by Rienstra et al. [32], the reference interval for sST2 was reported as $9-50 \mathrm{ng} / \mathrm{mL}$ in males $(\mathrm{n}=245)$ and $7-3 \mathrm{ng} / \mathrm{mL}$ in females ( $n=245)$. Lu et al. [33] reported that the plasma level of sST2 was unaffected by age, but was higher in males compared with females in the US population. Wang et al. [34] suggested that age, BMI, systolic blood pressure, diastolic blood pressure, and smoking did not affect the plasma sST2 level, and that the major influencing factor of sST2 level in the Chinese population was gender.

According to the results of the Framingham Heart Study, there was a significant difference between male and female subjects in plasma sST2 level; the reference interval for sST2 was 11-45 ng/mL in males $(\mathrm{n}=462)$ and $9-35 \mathrm{ng} / \mathrm{mL}$ in females. Additionally, in this well-characterized, community-based cohort study, it was reported that the plasma concentration of sST2 measured with ELISA increased with age, was associated with diabetes and hypertension, and was not significantly affected by BMI or renal impairment [35].

Mayo Medical Laboratories [36] found a median sST2 plasma concentration of $52.0 \mathrm{ng} / \mathrm{mL}$ for males (>18 years) and 38.7 $\mathrm{ng} / \mathrm{mL}$ for females (>18 years) using ELISA. The median normal concentration of ST2 was reported as $18 \mathrm{ng} / \mathrm{mL}$ and con- centrations greater than $35 \mathrm{ng} / \mathrm{mL}$ were strongly indicative of increased HF risk [36].

In a recently published Korean study, it was reported that gender-specific reference intervals should be used for the Korean population and that the use of a single cut-off value of $35 \mathrm{ng} /$ $\mathrm{mL}$ cited in previous studies could be overcautious and result in the possibility of false positivity, especially in men [37]. Mueller et al.[28] measured median sST2 plasma concentration using 3 different assays and found that the median sST2 plasma concentration was $43.5 \mathrm{ng} / \mathrm{mL}, 0.375 \mathrm{ng} / \mathrm{mL}$, and 0.144 $\mathrm{ng} / \mathrm{mL}$. Their results suggested that there was a significant difference in the serum sST2 level according to the used method.

\section{Soluble ST2 and Heart Failure}

Despite the potential role played by ST2 in inflammation, it has been suggested that there were significant parallel effects between ST2 and natriuretic peptides. This result indicated that ST2 represented a bridge between the inflammatory and neurohormonal systems $[37,38]$. The emergency diagnosis of acute HF starts with clinical presentation and radiographic examination [4, 5]. Although BNP has been accepted as useful in the diagnosis and risk stratification of HF, the diagnostic accuracy of the BNP level between 100 and $500 \mathrm{pg} / \mathrm{mL}$ has been limited, and is referred to as the "BNP gray zone." It not clear if the determination of sST2 and BNP level in the gray zone supported the clinical diagnosis. It is noteworthy that there are controversial results in published studies.

The results from the PRIDE (Pro-Brain Natriuretic Peptide Investigation of Dyspnea in the Emergency Department) study [39] suggested that among dyspneic patients with and without acute HF, ST2 concentration is strongly predictive of mortality at 1 year and might be useful for prognostication when used alone or together with NT-proBNP.

Mueller et al. [40] investigated the sST2 level in patients with acute destabilized HF for 1 year and reported that median concentrations of sST2 were significantly higher in acute HF patients than in those without HF (0.50 vs $0.15 \mathrm{ng} / \mathrm{mL})$ and that there was a strong relationship between sST2 concentration and 1-year mortality.

Henry-Okafor et al. [41] investigated the diagnostic and prognostic roles of sST2 and whether there was a diagnostic contribution of sST2 in patients with suspected HF. They used modified Framingham criteria for acute HF and outcome measures were final diagnosis of acute HF and 5- and 30-day adverse events. The sST2 concentration was higher in patients with HF in unadjusted analyses, but the authors indicated that there was a low diagnostic utility of SST2 after adjusting for a history of aspirin and steroid use, age, gender, race, and BMI. Their results also showed that SST2 did not add significant information to BNP in the diagnosis or prognosis. In another study [42], it was demonstrated that serial sampling of ST2 was predictive of 90-day mortality following acute destabilized HF and that the percent change in ST2 was equivalent to the percent change in NT-proBNP, and that both of these biomarkers 
were better at predicting 90-day mortality than the percent change in BNP.

Weinberg et al. [43] reported that a change in ST2 level, but not the baseline ST2, was predictive of 30-day mortality in patients with chronic HF. Rehman et al. [44] suggested that prognostically, ST2 was powerful in acute HF and was synergistic with natriuretic peptides for this purpose, and that the highest rate of death was observed when both ST2 and natriuretic peptides were elevated in cumulative hazard analysis.

Hughes et al. [45] measured high-sensitivity SST2 in 8444 men and women (age range: $25-74$ years) in the national FINRISK97 prospective population cohort of Finland. They evaluated the ability of sST2 to predict fatal and non-fatal HF; cardiovascular disease, including coronary heart disease and stroke; diabetes; and death over 15 years of follow-up. Their results indicated that in a healthy population from Finland, sST2 did not improve long-term prediction of cardiovascular events, including $\mathrm{HF}$, or all-cause mortality, and that SST2 did not significantly improve prediction in addition to the Framingham risk factors alone or adjusted for NT-proBNP. They claimed that SST2 should not be considered for incorporation into risk scores for primary prevention of cardiovascular diseases.

Wang et al. [46] found that the use of multiple biomarkers in patients with cardiovascular stress added to the prognostic value of standard risk factors for $\mathrm{HF}$ and cardiovascular events. Tomaschitz et al. [47] suggested that there was further exploration to be done of sST2 and molecular mechanisms before they could meet the 9-step criteria ( 6 of which were recommended by the American Heart Association [48], and 3 were recommended by European Society of Cardiology Working Group [49]) on biomarkers for peripheral circulation.

Recommendations regarding the role of sST2 in general population-based testing, as formulated by the International ST2 Consensus Panel A, were presented by Ho et al. [50] They indicated that there might be a role for $\mathrm{SST} 2$ in the prediction of cardiovascular outcomes, potentially in a multimarker strategy including troponins and BNP, but the role of soluble ST2 testing in the general population has not yet been conclusively established. It also noted that future studies are needed to examine the clinical utility of soluble ST2 screening in the general population [50].

Recently, a novel, chronic HF risk tool, the Barcelona BioHeart Failure Risk Calculator (www.BCNBioHFcalculator.cat), was developed, and it incorporated clinical and biochemical biomarkers, including SST2, high-sensitivity cardiac troponin $\mathrm{T}$, and NT-proBNP in chronic HF patients [51]. It has been reported that the multiple biomarker approach used by the new HF risk-calculator may be suitable for different pathophysiological pathways involved the prediction of death at 1,2, and 3 years. However, the clinical routine outcomes of the use of this risk calculator are not yet clear; it requires further validation.

Additionally, the effects of therapy on the level of blood sST2 are not clear, and investigations are limited. Anand et al. [52] reported that, compared with a placebo, an angiotensin-con- verting enzyme (ACE)-inhibitor or beta blocker significantly reduced the rate of increase in $\mathrm{SST} 2$, whereas digoxin and diuretics were associated with higher concentrations ACE-inhibitors and beta-blockers were associated with lower SST2 concentrations in the Valsartan Heart Failure Trial. The results of the CORONA (Controlled Rosuvastatin Multinational Trial in Heart Failure) study demonstrated that the mean SST2 level did not change for 3 months in treatment groups of patients with chronic HF [53]. The PROTECT (pro-BNP Outpatient Tailored Chronic Heart Failure Therapy) group assessed the response of SST2 to medications. The investigators found that changing the dose of a beta-blocker might affect the SST2 concentration in HF [54]. Miller et al. [23] published a review indicating a role for IL-33 and its receptor, ST2L, within cardiovascular disease, and the potential use of SST2 as a predictive cardiovascular biomarker.

\section{Conclusion}

The ST2/IL-33 pathway is involved in pathophysiology of myocardial dysfunction by potentially attenuating the cardioprotective effects of IL-33 as a result of reducing the extent of cardiac damage after cardiovascular events. SST2 could prevent the effects of IL-33/ST2L interaction. Measurements of blood SST2 level could be of clinical prognostic value in risk stratification of patients with myocardial infarction, $\mathrm{HF}$, and dyspnea. Further studies are needed for a routine use of SST2 in HF. The main points for ST2 are:

1. ST2 is a clinically relevant biomarker reflecting pathophysiological processes bridging the inflammatory and neurohormonal systems, and may provide predictive information in several cardiovascular diseases, especially HF.

2. The utility of SST2 testing in the general population has not yet been established. Both community-based population studies and biological variation studies in patients with healthy and diseased status should be performed.

3. There was a significant difference in the plasma SST2 concentration of healthy patients based on gender in all of the methods examined: the blood sST2 level was higher in males than in females.

4. There are some methodological problems with the SST2 assay. Improving the analytical performance would likely improve the predictive value of the ST2 assay.

5. The method-based variations in blood SST2 levels should not be forgotten in patients with healthy or diseased status.

6. HF may be an important cause of a rise in $\mathrm{SST} 2$, but other pathologial processes, including inflammatory diseases (sepsis, heart diseases) may also lead to an increase. Therefore, sST2 may be considered a useful prognostic marker for such diseases.

7. IL-33/ST2L/sST2 proteins have distinct functions in different cells within different biological systems; more knowledge about the regulation of these systems is required. More 
research of the role of ST2 for both therapeutic intervention and in the development and progression of atherosclerosis is needed.

8. It seems that the measurement of $\mathrm{SST} 2$ on admission might be a strong and independent prognostic biomarker in patients with acute and chronic HF. Serial measurement of sST2 theoretically could assist with therapeutic decisions for patients with HF.

Conflict of interest: None declared.

\section{References}

1. Bui AL, Horwich TB, Fonarow GC. Epidemiology and risk profile of heart failure. Nat Rev Cardiol 2011;8:30-41. [CrossRef]

2. Roger VL. Epidemiology of heart failure. Circ Res 2013;113:64659. [CrossRef]

3. Yancy CW, Jessup M, Bozkurt B, Butler J, Casey DE Jr, Drazner $\mathrm{MH}$, et al. 2013 ACCF/AHA guideline for the management of heart failure: a report of the American College of Cardiology Foundation/American Heart Association Task Force on Practice Guidelines. J Am Coll Cardiol 2013;62:e147-239. [CrossRef]

4. Ponikowski P, Voors AA, Anker SD, Bueno H, Cleland JG, Coats AJ, et al. 2016 ESC Guidelines for the diagnosis and treatment of acute and chronic heart failure: The Task Force for the diagnosis and treatment of acute and chronic heart failure of the European Society of Cardiology (ESC). Developed with the special contribution of the Heart Failure Association (HFA) of the ESC. Eur J Heart Fail 2016;18:891-975. [CrossRef]

5. Jneid H, Addison D, Bhatt DL, Fonarow GC, Gokak S, Grady KL, et al. 2017 AHA/ACC Clinical Performance and Quality Measures for Adults With ST-Elevation and Non-ST-Elevation Myocardial Infarction: A Report of the American College of Cardiology/American Heart Association Task Force on Performance Measures. J Am Coll Cardiol 2017;70:2048-90. [CrossRef]

6. Mahadavan G, Nguyen TH, Horowitz JD. Brain natriuretic peptide: a biomarker for all cardiac disease? Curr Opin Cardiol 2014;29:160-6. [CrossRef]

7. Maries L, Manitiu I. Diagnostic and prognostic values of B-type natriuretic peptides (BNP) and N-terminal fragment brain natriuretic peptides (NT-pro-BNP). Cardiovasc J Afr 2013;24:2869. [CrossRef]

8. Torre M, Jarolim P. Cardiac troponin assays in the management of heart failure. Clin Chim Acta 2015;441:92-8. [CrossRef]

9. Ghashghaei R, Arbit B, Maisel AS. Current and novel biomarkers in heart failure: bench to bedside. Curr Opin Cardiol 2016;31:191-5. [CrossRef]

10. Ciccone MM, Cortese F, Gesualdo M, Riccardi R, Di Nunzio D, Moncelli $M$, et al. A novel cardiac bio-marker: ST2: a review. Molecules 2013;18:15314-28. [CrossRef]

11. Pascual-Figal DA, Januzzi JL. The biology of ST2: the International ST2 Consensus Panel. Am J Cardiol 2015;115:3B-7B.

12. Kuroiwa K, Arai T, Okazaki H, Minota S, Tominaga S. Identification of human ST2 protein in the sera of patients with autoimmune diseases. Biochem Biophys Res Commun
2001;284:1104-8. [CrossRef]

13. Hur M, Kim H, Kim HJ, Yang HS, Magrini L, Marino R, et al. Soluble ST2 has a prognostic role in patients with suspected sepsis. Ann Lab Med 2015;35:570-7. [CrossRef]

14. Trajkovic V, Sweet MJ, Xu D. T1/ST2-an IL-1 receptor- like modulator of immune responses. Cytokine Growth Factor Rev 2004;15:87-95. [CrossRef]

15. Schmitz J, Owyang A, Oldham E, Song Y, Murphy E, McClanahan TK, et al. IL-33, an interleukin-1-like cytokine that signals via the IL-1 receptor-related protein ST2 and induces T helper type 2-associated cytokines. Immunity 2005 ;23:479e490.

16. Seyfizadeh N, Seyfizadeh N, Gharibi T, Babaloo Z. Interleukin-13 as an important cytokine: A review on its roles in some human diseases. Acta Microbiol Immunol Hung 2015;62:341-78.

17. Lécart S, Lecointe $N$, Subramaniam A, Alkan S, Ni D, Chen R, et al. Activated, but not resting human Th2 cells, in contrast to Th1 and T regulatory cells, produce soluble ST2 and express low levels of ST2L at the cell surface. Eur J Immunol 2002;32:2979-87. [CrossRef]

18. Takezako N, Hayakawa M, Hayakawa H, Aoki S, Yanagisawa K, Endo $\mathrm{H}$, et al. ST2 suppresses IL-6 production via the inhibition of IkappaB degradation induced by the LPS signal in THP-1 cells. Biochem Biophys Res Commun 2006;341:425-32. [CrossRef]

19. Tajima S, Bando M, Ohno S, Sugiyama Y, Oshikawa K, Tominaga S, et al. ST2 gene induced by type 2 helper T cell (Th2) and proinflammatory cytokine stimuli may modulate lung injury and fibrosis. Exp Lung Res 2007;33:81-97. [CrossRef]

20. Weinberg EO, Shimpo M, De Keulenaer GW, MacGillivray C, Tominaga S, Solomon SD, et al. Expression and regulation of ST2, an interleukin-1 receptor family member, in cardiomyocytes and myocardial infarction. Circulation 2002;106:29616. [CrossRef]

21. Sanada S, Hakuno D, Higgins LJ, Schreiter ER, McKenzie AN, Lee RT. IL-33 and ST2 comprise a critical biomechanically induced and cardioprotective signaling system. J Clin Invest 2007;117:1538-49. [CrossRef]

22. Seki K, Sanada S, Kudinova AY, Steinhauser ML, Handa V, Gannon J, et al. Interleukin-33 prevents apoptosis and improves survival after experimental myocardial infarction through ST2 signaling. Circ Heart Fail 2009;2:684-91. [CrossRef]

23. Miller AM, Liew FY. The IL-33/ST2 pathway-A new therapeutic target in cardiovascular disease. Pharmacol Ther 2011;131:179-86. [CrossRef]

24. Sánchez-Más J, Lax A, Asensio-López Mdel C, Fernandez-Del Palacio MJ, Caballero L, Santarelli G, et al. Modulation of IL-33/ ST2 system in postinfarction heart failure: correlation with cardiac remodelling markers. Eur J Clin Invest 2014;44:643-51.

25. Miller AM, Xu D, Asquith DL, Denby L, Li Y, Sattar N, et al. IL33 reduces the development of atherosclerosis. J Exp Med 2008;205:339-46. [CrossRef]

26. De la Fuente M, MacDonald TT, Hermoso MA. The IL-33/ST2 axis: Role in health and disease. Cytokine Growth Factor Rev 2015;26:615-23. [CrossRef]

27. Dieplinger B, Januzzi JL Jr, Steinmair M, Gabriel C, Poelz W, Haltmayer $M$, et al. Analytical and clinical evaluation of 
a novel high-sensitivity assay for measurement of soluble ST2 in human plasma-the Presage ST2 assay. Clin Chim Acta 2009;409:33-40. [CrossRef]

28. Mueller T, Zimmermann M, Dieplinger B, Ankersmit HJ, Haltmayer M. Comparison of plasma concentrations of soluble ST2 measured by three different commercially available assays: the MBL ST2 assay, the Presage ST2 assay, and the R\&D ST2 assay. Clin Chim Acta 2012;413:1493-4. [CrossRef]

29. Mueller T, Jaffe AS. Soluble ST2-analytical considerations. Am J Cardiol 2015;115:8B-21B. [CrossRef]

30. Dieplinger B, Egger M, Poelz W, Haltmayer M, Mueller T. Longterm stability of soluble ST2 in frozen plasma samples. Clin Biochem 2010;43:1169-70. [CrossRef]

31. Wu AH, Wians F, Jaffe A. Biological variation of galectin-3 and soluble ST2 for chronic heart failure: implication on interpretation of test results. Am Heart J 2013;165:995-9. [CrossRef]

32. Rienstra M, Yin X, Larson MG, Fontes JD, Magnani JW, McManus DD, et al. Relation between soluble ST2, growth differentiation factor-15, and high-sensitivity troponin I and incident atrial fibrillation. Am Heart J 2014;167:109-15.e2. [CrossRef]

33. Lu J, Snider JV, Grenache DG. Establishment of reference intervals for soluble ST2 from a United States population. Clin Chim Acta 2010;411:1825-6. [CrossRef]

34. Wang Y, Zhang Y, An T, Zhang R, Zhao X, Liu N, et al. ErbB4 Gene Polymorphism Is Associated With the Risk and Prognosis of Congestive Heart Failure in a Northern Han Chinese Population. J Card Fail 2016;22:700-9. [CrossRef]

35. Coglianese EE, Larson MG, Vasan RS, Ho JE, Ghorbani A, McCabe EL, et al. Distribution and clinical correlates of the interleukin receptor family member soluble ST2 in the Framingham Heart Study. Clin Chem 2012;58:1673-81. [CrossRef]

36. https://www.mayomedicallaboratories.com/test catalog/Clinical+and+Interpretive/61723. Accessed Dec 12, 2017.

37. Park M, Ji M, Kim H, Moon HW, Hur M, Yun YM. Establishing Reference Intervals for Soluble ST2 Assay in a Korean Population. Lab Med Online 2017;7:176-81. [CrossRef]

38. Bruneau BG, de Bold AJ. Selective changes in natriuretic peptide and early response gene expression in isolated rat atria following stimulation by stretch or endothelin-1. Cardiovasc Res 1994;28:1519-25. [CrossRef]

39. Januzzi JL Jr, Peacock WF, Maisel AS, Chae CU, Jesse RL, Baggish $A L$, et al. Measurement of the interleukin family member ST2 in patients with acute dyspnea: results from the PRIDE (Pro-Brain Natriuretic Peptide Investigation of Dyspnea in the Emergency Department) study. J Am Coll Cardiol 2007;50:60713. [CrossRef]

40. Mueller T, Dieplinger B, Gegenhuber A, Poelz W, Pacher R, Haltmayer M. Increased plasma concentrations of soluble ST2 are predictive for 1-year mortality in patients with acute destabilized heart failure. Clin Chem 2008;54:752-6. [CrossRef]

41. Henry-Okafor Q, Collins SP, Jenkins CA, Miller KF, Maron DJ, Naftilan AJ, et al. Soluble ST2 as a Diagnostic and Prognostic Marker for Acute Heart Failure Syndromes. Open Biomark J 2012;2012:1-8. [CrossRef]

42. Boisot S, Beede J, Isakson S, Chiu A, Clopton P, Januzzi J, et al. Serial sampling of ST2 predicts 90-day mortality following destabilized heart failure. J Card Fail 2008;14:732-8. [CrossRef]

43. Weinberg EO, Shimpo M, Hurwitz S, Tominaga S, Rouleau JL, Lee RT. Identification of serum soluble ST2 receptor as a novel heart failure biomarker. Circulation 2003;107:721-6. [CrossRef]

44. Rehman SU, Mueller T, Januzzi JL Jr. Characteristics of the novel interleukin family biomarker ST2 in patients with acute heart failure. J Am Coll Cardiol 2008;52:1458-65. [CrossRef]

45. Hughes MF, Appelbaum S, Havulinna AS, Jagodzinski A, Zeller T, Kee F, et al. ST2 may not be a useful predictor for incident cardiovascular events, heart failure and mortality. Heart 2014;100:1715-21. [CrossRef]

46. Wang TJ, Wollert KC, Larson MG, Coglianese E, McCabe EL, Cheng $S$, et al. Prognostic utility of novel biomarkers of cardiovascular stress: the Framingham Heart Study. Circulation 2012;126:1596-604. [CrossRef]

47. Tomaschitz A, Pilz S, März W. GDF-15, soluble ST2 and Troponin-I: Biomarkers of Subclinical Vascular Disease? Atherosclerosis 2016;248:255-6. [CrossRef]

48. Hlatky MA, Greenland P, Arnett DK, Ballantyne CM, Criqui MH, Elkind MS, et al. Criteria for evaluation of novel markers of cardiovascular risk: a scientific statement from the American Heart Association. Circulation 2009;1 19:2408-16. [CrossRef]

49. Vlachopoulos C, Xaplanteris P, Aboyans V, Brodmann M, Cífková $\mathrm{R}$, Cosentino $\mathrm{F}$, et al. The role of vascular biomarkers for primary and secondary prevention. A position paper from the European Society of Cardiology Working Group on peripheral circulation: Endorsed by the Association for Research into Arterial Structure and Physiology (ARTERY) Society. Atherosclerosis 2015;241:507-32. [CrossRef]

50. Ho JE, Sritara P, deFilippi CR, Wang TJ. Soluble ST2 testing in the general population. Am J Cardiol 2015;115:22B-5B.

51. Lupón J, de Antonio M, Vila J, Peñafiel J, Galán A, Zamora E, et al. Development of a novel heart failure risk tool: the barcelona bio-heart failure risk calculator (BCN bio-HF calculator). PLoS One 2014;9:e85466. [CrossRef]

52. Anand IS, Rector TS, Kuskowski M, Snider J, Cohn JN. Prognostic value of soluble ST2 in the Valsartan Heart Failure Trial. Circ Heart Fail 2014;7:418-26. [CrossRef]

53. Bayes-Genis A, de Antonio M, Galán A, Sanz H, Urrutia A, Cabanes $R$, et al. Combined use of high-sensitivity ST2 and NTproBNP to improve the prediction of death in heart failure. Eur J Heart Fail 2012;14:32-8. [CrossRef]

54. Gaggin HK, Motiwala S, Bhardwaj A, Parks KA, Januzzi JL Jr. Soluble concentrations of the interleukin receptor family member ST2 and $\beta$-blocker therapy in chronic heart failure. Circ Heart Fail 2013;6:1206-13. [CrossRef]

55. Miyagaki T, Sugaya M, Yokobayashi H, Kato T, Ohmatsu H, Fujita $\mathrm{H}$, et al. High levels of soluble ST2 and low levels of IL33 in sera of patients with HIV infection. J Invest Dermatol 2011;131:794-6. [CrossRef]

56. Bradley-Stewart A, Jolly L, Adamson W, Gunson R, Frew-Gillespie C, Templeton $\mathrm{K}$, et al. Cytokine responses in patients with mild or severe influenza $A(\mathrm{H} 1 \mathrm{~N} 1)$ pdm09. J Clin Virol 2013;58:100-7. [CrossRef] 
57. Vocca L, Di Sano C, Uasuf CG, Sala A, Riccobono L, Gangemi $\mathrm{S}$, et al. IL-33/ST2 axis controls Th2/IL-31 and Th17 immune response in allergic airway diseases. Immunobiology 2015;220:954-63. [CrossRef]

58. Roth GA, Zimmermann M, Lubsczyk BA, Pilz J, Faybik P, Hetz H, et al. Up-regulation of interleukin 33 and soluble ST2 serum levels in liver failure. J Surg Res 2010;163:e79-83. [CrossRef]

59. Sun Y, Zhang JY, Lv S, Wang H, Gong M, Du N, et al. Interleukin-33 promotes disease progression in patients with primary biliary cirrhosis. Tohoku J Exp Med 2014;234:255-61.

60. Bergis D, Kassis V, Radeke HH. High plasma sST2 levels in gastric cancer and their association with metastatic disease. Cancer Biomark 2016;16:117-25. [CrossRef]

61. Lu DP, Zhou XY, Yao LT, Liu CG, Ma W, Jin F, et al. Serum soluble ST2 is associated with ER-positive breast cancer. BMC Cancer 2014; 14:198. [CrossRef]

62. Bergis D, Kassis V, Ranglack A, Koeberle V, Piiper A, Kronenberger B, et al. High Serum Levels of the Interleukin-33 Receptor Soluble ST2 as a negative prognostic factor in hepatocellular carcinoma. Transl Oncol 2013;6:311-8. [CrossRef]

63. Lin YH, Zhang RC, Hou LB, Wang KJ, Ye ZN, Huang T, et al. Distribution and clinical association of plasma soluble ST2 during the development of type 2 diabetes. Diabetes Res Clin Pract 2016;118:140-5. [CrossRef]

64. Zeyda M, Wernly B, Demyanets S, Kaun C, Hämmerle $M$, Hantusch B, et al. Severe obesity increases adipose tissue expression of interleukin-33 and its receptor ST2, both predominantly detectable in endothelial cells of human adipose tissue. Int J Obes (Lond) 2013;37:658-65. [CrossRef]

65. Beltrán CJ, Núñez LE, Díaz-Jiménez D, Farfan N, Candia E, Heine $C$, et al. Characterization of the novel ST2/IL-33 system in patients with inflammatory bowel disease. Inflamm Bowel Dis 2010;16:1097-107. [CrossRef]

66. Shimizu M, Matsuda A, Yanagisawa K, Hirota T, Akahoshi M, Inomata $\mathrm{N}$, et al. Functional SNPs in the distal promoter of the ST2 gene are associated with atopic dermatitis. Hum Mol Genet 2005;14:2919-27. [CrossRef]
67. Talabot-Ayer D, Mckee T, Gindre P, Bas S, Baeten DL, Gabay C, et al. Distinct serum and synovial fluid interleukin (IL)-33 levels in rheumatoid arthritis, psoriatic arthritis and osteoarthritis. Joint Bone Spine 2012;79:32-7. [CrossRef]

68. Margiotta DP, Navarini L, Vadacca M, Lo Vullo M, Pignataro F, Basta F, et al. The IL33/ST2 axis in Sjogren syndrome in relation to disease activity. Eur Rev Med Pharmacol Sci 2016;20:12959.

69. Mok MY, Huang FP, Ip WK, Lo Y, Wong FY, et al. Serum levels of IL-33 and soluble ST2 and their association with disease activity in systemic lupus erythematosus. Rheumatology (Oxford) 2010;49:520-7. [CrossRef]

70. Kim DJ, Baek SY, Park MK, Park KS, Lee JH, Park SH, et al. Serum level of interleukin-33 and soluble ST2 and their association with disease activity in patients with Behcet's disease. J Korean Med Sci 2013;28:1145-53. [CrossRef]

71. Fu AK, Hung KW, Yuen MY, Zhou X, Mak DS, Chan IC, et al. IL-33 ameliorates Alzheimer's disease-like pathology and cognitive decline. Proc Natl Acad Sci U S A 2016;113:E2705-13. [CrossRef]

72. Lin CY, Pfluger CM, Henderson RD, McCombe PA. Reduced levels of interleukin 33 and increased levels of soluble ST2 in subjects with amyotrophic lateral sclerosis. J Neuroimmunol 2012;249:93-5. [CrossRef]

73. Andersson C, Preis SR, Beiser A, DeCarli C, Wollert KC, Wang $\mathrm{TJ}$, et al. Associations of circulating growth differentiation factor-15 and ST2 concentrations with subclinical vascular brain injury and Incident Stroke. Stroke 2015;46:2568-75. [CrossRef]

74. Homsak E, Ekart R. ST2 as a novel prognostic marker in endstage renal disease patients on hemodiafiltration. Clin Chim Acta 2017;477:105-12. [CrossRef]

75. Zhang Z, Liu X, Wang H, Qu Z, Crew R, Zhang N, et al. Increased soluble ST2 and IL-4 serum levels are associated with disease severity in patients with membranous nephropathy. Mol Med Rep 2018;17:2778-86. 